\title{
En teknologi på grænsen - det etiske hensyn og det fælles bedste
}

\author{
Mikkel Bøhm, Jan Bendtzen, Michael Jensen \& Martin Brix Larsen
}

Forestil dig, at et lille kamera optager alt, hvad du siger, og alt hvad du gør, mens du passer dit arbejde. Tilsæt da hektiske situationer med ufuldstændig information og et markant handlepres, så har du den situation, som nogle af beredskabets holdledere og indsatsledere sættes i. Formålet med brugen af kropskameraer i beredskabet er læring, og erfaringerne viser, at disse kropskameraer er i stand til at initiere reflekterende og refleksive læreprocesser på en anderledes produktiv måde, end nogen anden teknologi tidligere har været i stand til. Udfordringen er at balancere, hvordan en sådan teknologi kan bidrage med tilstrækkelig stor værdi, selvom den potentielt set medfører uproduktive påvirkninger af individet. Kropskameraer bliver derved uomtvisteligt en teknologi på grænsen, der udfordrer balancen mellem det etiske hensyn til individet og det samlede læringsudbytte for det fælles bedste.

Nøgleord: Beredskab, etik, indsatsledelse, læring, teknologi.

\section{Indledning}

Selvom vores arbejdsliv på væsentlige måder er anderledes, end det var tilfældet i 1899, så er det stadig intentionerne i hovedaftalens rettigheder og pligter fra dengang, som i dag er gældende for forholdet mellem arbejdsgiveren og lønmodtageren. Det er lederen, der har instruktionsretten, og det er arbejdsgiveren, der beskriver, hvad der skal laves, hvem der skal forestå arbejdet, hvordan arbejdet skal laves, herunder hvilke standarder og metoder arbejdet skal følge (Due \& Madsen, 1999). En væsentlig grænse i ledelsesretten er, at arbejdsgiveren skal sikre, at arbejdsmiljøet ikke kan skade lønmodtageren fysisk såvel som psykisk.
Artiklens fokus er rettet mod det psykiske arbejdsmiljø i forbindelse med brugen af kropskamera, der er monteret på holdledere og indsatsledere under operative indsatser, som eksempelvis bygningsbrande og trafikuheld. Kameraer, som en integreret del af vores arbejdsliv, kan betegnes som en teknologi, der på flere måder befinder sig på grænsen. Teknologien kan potentielt udfordre medarbejdernes psykiske arbejdsmiljø ved at eksponere fejl og afvigelser i forbindelse med arbejdets udførelse. Brugen af denne type af teknologi fordrer altså, at arbejdsgiveren, i samarbejde med lønmodtagerne, forholder sig til de etiske dilemmaer, som brugen af kropskameraer medfører. De etiske 
dilemmaer opstår i spændingsfeltet mellem det læringsmæssige udbytte, som kropskameraer giver, og den potentielle eksponering af individuelle fejl og mangler. Spørgsmålet bliver derfor, om værdien af den konkrete brug reelt set kan forsvare de potentielle uproduktive påvirkninger, som en eksponering af individet kan medføre. Artiklen tager afsæt i det paradoks, at det, vi skal lære af, samtidig er det, der potentielt set gør os mest ondt. Det, der potentielt gør os mest ondt, bidrager på den ene side med en energi og en oplevelse af nødvendighed, der kan tilføre læreprocesser markant motivation. På den anden side, så kan denne type af læring utilsigtet komme til at fokusere på skyld og skam, hvilket i højere grad kan tvinge den enkelte til at bortforklare eller undskylde sin adfærd. Alt sammen faktorer, der i bund og grund hindrer en nysgerrig reflekterende og refleksiv læreproces.

Selvom der i enhver ansættelsesrelation opstår et asymmetrisk forhold mellem medarbejder og leder, så er der nogle professioner, hvor fejl eller misforståelser kan få fatale konsekvenser. Her tænker vi eksempelvis på sundhedsprofessionelle, politi- og brandfolk, der agerer i et ofte hektisk miljø. Når disse aktører agerer på et skadested, så er der en forventning om, at de handler. Disse handlinger bliver ofte udøvet under markant tidspres, og involverer ofte ufuldstændig information. Netop grundet tids- og handlepresset er kameraoptagelser en værdsat læringsunderstøttende teknologi, der er i stand til at fastholde den situerede hændelse. Det bliver derved muligt for den enkelte at gense optagelsen, og derved bruge videoen aktivt i de efterfølgende læreprocesser.

I forlængelse af ovenstående, undersøger artiklen: hvordan arbejdet med videooptagelser fra operative indsatser kan tilretteloegges, så det skaber loering til gloede for det foelles bedste, uden at det samtidig indskriver en uetisk sårbarhed knyttet til det enkelte individ?
Det valgte forskningsspørgsmål bliver undersøgt med afsæt i brugen af kropskamera i beredskabet (brandvæsenet). Casen tager afsæt i Beredskab Øst, der et det beredskab, som dækker kommunerne i Ballerup, Gentofte, Gladsaxe, Herlev og Lyngby-Taarbæk. Udrykningsområdet i de fem kommuner dækker i alt ca. 300.000 borgere. Som forfattergruppe er vi til dagligt ansat som beredskabsinspektører i Beredskab Øst, hvor vi, foruden vores operative opgaver, arbejder i "teamet for intern uddannelse og læring" (herefter kaldet læringsteamet) med henblik på understøtte organisationens individuelle- og kollektive læreprocesser. Artiklen omhandler for det første de konsekvensetiske dilemmaer, der opstår i forhold til at afbalancere hensynet til individet over for kollektivets læreprocesser på baggrund af optagelser fra operative indsatser. For det andet problematiserer artiklen også læringsteamets rolle. Læringsteamet er sat i verden for at få så meget læring ud i organisationen som muligt, men det er samtidig læringsteamets opgave at varetage og beskytte individets lyst til at lære.

\section{Konsekventialisme - loering for alles bedste}

Konsekvensetik eller nytteetik vurderer, hvorvidt handlinger er moralske eller ej, ud fra en vurdering af den grad af nytte eller lykke, som en handling medfører (Diderichsen, 2011, s.24). Udfordringerne med et konsekvensetisk udgangspunkt er, at lykkeregnskabet bliver både spekulativt og enormt indviklet (Diderichsen, 2011, s. 41). Det er utrolig vanskeligt at prissætte den totale sum af læring for organisationens medlemmer versus de totale omkostninger for de enkelte individer. Selvom regnestykket bliver utrolig vanskeligt, så fylder det konsekvensetiske perspektiv væsentligt i praksis. Et eksempel på dette er eksempelvis de godkendelser, der ligger til grund for implementering og bru- 
gen af kamera ved politiet og brandvæsenet i Norge (Bøhm, 2017). Her fremgår det, af svaret fra "Norsk Samfundsvidenskabelig Datatjeneste", samt svaret fra "Politihøgskolens" ekspertråd, at selvom der er en række udfordringer i forhold til hensynet til 3. person, fritagelse fra tavshedspligten samt brugen af kamera i det offentlige rum, så overstiger det erkendelsesmæssige formål disse præskriptive anker. På baggrund af forskning gennemført ved brandvæsener i Danmark og Norge, så beror artiklen på den præmis, at optagelser fra kropskameraer udgør en af de væsentligste kilder til læring fra operative indsatser (Bøhm, 2017). Et kropskamera er i stand til at optage det, der sker i nuet, på et skadested, hvor den enkelte brandmand, holdleder eller indsatsleder agerer i et hektisk miljø, der i nuet kan være vanskeligt at begribe. Brugen af kropskamera giver med andre ord indsigt $i$ en praksis, som det er vanskeligt at genskabe, og hvor der indgår mange variable, som kan være vanskelige at overskue. Udfordringen med kamerateknologi er, at fokus på læring kan skifte til overvågning, blot ved at beskueren ændrer sit perspektiv fra læring til fejl og afvigelser.

\section{Datalovgivning og samtykke}

I forhold til politiets såvel som beredskabets operative virke, så opstår der udfordringer i forhold til at opnå fri samtykke fra 3. person. Hensynet til 3. person, som potentielt set ufrivilligt bliver gjort til genstand for undersøgelse, er et fokuspunkt fra datatilsynet. Myndighederne er særligt nervøse for, at man via de privilegerede positioner, som brandvæsenet, politiet samt sundhedsberedskabet har, kan tilgå særlig sensitiv information, der potentielt set kan være særdeles krænkende. Derfor skal disse personer i sagens natur anonymiseres. I forhold til 3. person opstår der også den væsentlige udfordring, at det er vanskeligt at opnå en reel fri samtykke.
Det giver sig selv, at det er vanskeligt at få en samtykke fra en person, som beredskabet møder i forbindelse med et trafikuheld eller en lejlighedsbrand. Disse personer er i sagens natur ufrivilligt kommet i kontakt med myndighederne, og det er ofte umuligt at hente den nødvendige samtykke efterfølgende (Bjørgo \& Myhrer, 2015, s. 11). I forhold til de ansatte, der benytter kamera på operative indsatser, så skal de enkelte personer give tilsagn til, at deres optagelser kan benyttes. De konkrete handlinger, som den enkelte udfører, kan ved hjælp af kameraet tages af en given sammenhæng, og bør derfor ikke anvendes uden forståelse for den konkrete kontekst, som den konkrete medarbejder agerer i (Bjørgo \& Myhrer, 2015, s. 13; Statens Samfundsvidenskabelige Forskningsråd).

\section{Kropskameraer - en læringsunderstøttende teknologi}

Udgangspunktet for at bruge kropskameraet, som en læringsunderstøttende teknologi, er kameraets unikke mulighed for at fastholde det situerede - altså hvad der skete, og hvem der gjorde hvad. Kropskameraet virker i den forbindelse som en løftestang i forhold til at udfordre det erfaringsparadigme, der er dominerende i beredskabsorganisationerne (Bøhm 2017, Sommer, 2015). Læreprocesserne i de danske beredskabsorganisationer har historisk set været baseret på mester- og sidemandsoplæring kombineret med formaliserede funktionsbaserede kurser (Bøhm, 2017; Sommer \& Njå, 2011, s. 445: Sommer, 2015). Udfordringen ved denne successive læringsforståelse er, at beredskabsorganisationernes læreprocesser ikke bliver evalueret eller udfordret af andre end beredskabsaktørerne selv (Sommer, 2015, s. 101). Det er altså beredskabet, der selv uddanner sine folk, og det er beredskabet, der selv vedligeholder træningen af deres folk. Det ender derved 
også med at blive beredskabet, der selv evaluerer deres operative praksis samt vurderer, hvornår en given kvalitet er acceptabel.

Kropskameraoptagelser gør det muligt for den enkelte at genopleve den faktiske operative indsats ved hjælp af kameraet. Indsatslederen eller holdlederen rejser populært sagt tilbage i tiden, og genoplever den situerede hændelse, og genoplever ikke mindst de forstyrrelser, som i nuet ramte dem. At blive ramt forstås inspireret af ledelses- og læringsforsker professor Ann Cunliffe, som "... our spontaneous response (emotional, physiological, cognitive) to events or relationships occurring..." (Cunliffe, 2002, s. 42). Der er altså netop tale om en type oplevelser, der sammenvæver emotioner, krop og kognition. At være ramt forstås som en begivenhed, der skaber en energi, og retter individets opmærksomhed mod at skabe mening. Igennem dialog udforskes oplevelsen af at blive ramt gennem reflekterende og refleksive processer. Indsatslederen reflekterer med andre ord over, hvad det er, der sker på optagelsen, og forholder sig refleksivt til, hvad det betyder for individet $\mathrm{i}$ indsatslederfunktionen. I denne artikel vælger vi at fokusere på de etiske dilemmaer, der opstår, når individet og kollektivet skal lære fra atypiske eller særlige hændelser. Denne type af hændelser kan potentielt set medføre, at individet kan blive eksponeret på en uhensigtsmæssig måde over for kollektivet. Dette skal dog ikke foranledige læseren til at tro, at opgaven med at analysere de operative hændelser udelukkende er at finde fejl og mangler. Det handler i lige så høj grad om at fastholde alt det, som fungerer godt. Valget med at betone de dilemmaer, hvor individet potentielt bliver eksponeret, er altså et analytisk greb for at anskueliggøre de etiske dilemmaer, som artiklen netop ønsker at diskutere balanceringen af.

Kropskameraet virker som en læringsunderstøttende teknologi. Læring bliver i forlængelse heraf opfattet som: “... an em- bodied, reflexive dialogical process in which we are struck and moved to reflect on and/ or reflexively question our ways of being and understanding" (Cunliffe, 2002, s. 42). Læringsaspektet bygger på det, som Cunliffe omtaler som "reflexive dialogue" og "reflective dialogue". Med "reflexive dialogical processes" forstår Cunliffe processer, hvor individet grundlæggende stiller spørgsmålstegn ved "our ways of understanding, being and acting in the world" (Cunliffe, 2002, s. 51). Reflekterende processer, “... draws on traditional assumptions that there is an objective reality that we can analyze using logic and theory... (Cunliffe, 2004, s. 414). Et eksempel på en sådan reflekterende proces kan illustreres med indsatslederen, der udforsker, hvordan det kan være, at netop den her ildebrand fik en så voldsom intensitet? Eller hvorfor brandforløbet afveg fra det, som man normalt ser? Formålet med en sådan proces er at erkende, hvorfor og hvordan individet og gruppen agerede, og hvilke forventninger individet og gruppen har til sig og hinanden fremadrettet (Cunliffe, 2004, s. 413). Den form for søgen, der sigtes efter her, er netop lig den søgen som eksempelvis Schön (1983), og Mezirow (1990) med indholds- og procesrefleksioner sigter efter. Refleksivitet forstås i højere grad som at trække på de ubevidste og ofte tavse antagelser, der ligger til grund for de handlinger og den samtalepraksis (conversational practice), som en person har, og minder derved i højere grad om det, som Mezirow omtaler som præmisrefleksioner. Cunliffe forstår refleksion på følgende måde “... critically reflexive questioning draws on social constructionist assumptions to highlight subjective, multiple, constructed realities" (Cunliffe, 2004, s. 414).

Gennem dialog er det muligt for den enkelte holdleder og indsatsleder at undersøge og udforske sin egen praksis ved at genopleve sin praksis i den faktiske sociale kontekst gennem kameraoptagelsen. De oplevelser fra 
at blive ramt, der bliver udforsket igennem dialog mellem individet og læringsteamets medlemmer, bliver herefter tematiseret og adresseret tilbage til indsatslederne og holdlederne på fælles informations- og læringsdage (temadage). Denne vekselvirkning er inspireret af Elkjær, der påpeger, at læring sker gennem udvikling af erfaringer, og at denne erfaringsdeling sker gennem: "... continuous transaction between the individual and the organization "through joint inquiry and/or reflective thinking" (Elkjær, 2004, s. 425). Gennemgangen på de efterfølgende informations- og læringsdage faciliteres af medlemmerne fra læringsteamet. Formålet med disse gennemgange er netop at dele den enkeltes refleksioner om at "blive ramt", ved brug af kameraoptagelser, fra konkrete operative hændelser. Det er derved hensigten at facilitere en kollektiv læreproces, hvor den enkelte holdleder eller indsatsleder kan spejle sig selv i det hændte. Den enkelte kan reflektere over den konkrete tekniske eller taktiske håndtering, men der er også et refleksivt element. Det refleksive element består $i$, at den enkelte indsatsleder eller holdleder kan spejle sin egen person i det hændte, og netop stille spørgsmålet, "hvad ville jeg have gjort, hvis jeg stod i samme situation". Udfordringen på disse læringsdage er dog netop at holde fokus på sagen og dekoble det fra det enkelte individ. Derved opstår den etiske afbalancering mellem hensynet til læring for kollektivet, over for hensynet til den enkelte, der i forbindelse med den konkrete gennemgang, direkte eller indirekte, bliver eksponeret $i$ at have ageret mere eller mindre uhensigtsmæssigt.

\section{En udforskning med afsæt i egen profession}

Arbejdet med at facilitere individuel og kollektiv læring bliver grundlæggende påvirket af, at vi som beredskabsinspektører i læringsteamet, ikke blot undersøger andres praksis, men i lige så høj grad er en aktiv del af denne praksis. Selvom læringsteamet systematisk udkondenserer forstyrrelser fra de enkelte optagelser, så vil en sådan tilskæring af "virkeligheden" altid være socialt konstrueret (Preissle \& Grant, 2004, s. 168). Læreprocessen vil derfor være et resultat af teamets tilstedeværelse i feltet. Denne form for "embedded research" fordrer en særlig opmærksomhed og refleksivitet knyttet til den rolle, vi som læringsteam har i feltet. Spradley (1980) oplister et kontinuum over forskellige deltagelsesformer gående fra ikke-deltagelse, passiv deltagelse, moderat deltagelse, aktiv deltagelse og komplet deltagelse. De cases, der er inkluderet $i$ analysen, er ikke indsatser, hvor læringsteamets medlemmer selv aktivt har deltaget. Vi har dog som team indgået aktivt i den efterfølgende bearbejdning, og derfor er der jo grundlæggende tale en komplet deltagelse.

Eftersom der er tale om udforskning af egen profession, har det været grundlæggende at udforske betydningen af, at vi som "læringsteam", er lige så meget "ethno", og lige så meget indhyllet i den kulturelle og sociale praksis, som de af vores kollegaer, som bliver gjort til genstand for undersøgelse (Watson, 2011, s. 212). Der opstår i den forbindelse potentielt "blinde pletter", hvor vi som læringsteam indirekte kommer til at søge efter de tendenser, som man tidligere har set, eller på anden måde kommer til at bekræfte vores egen selvforståelse. Det er derfor centralt at åbne sin praksis op, og netop diskutere sine læringsaktiviteter med andre professioner, for derigennem selv at blive udfordret til at reflektere over den praksis, som et aktivt forskersubjekt afstedkommer. Ifølge Lewis $\&$ Russel (2011), er der tre parametre, der kendetegner et aktiv forskersubjekt:

- "Co-presence of independence and familiarity" 
- "Relationsship between the researcher and collaborators - formative advice"

- "The dialectic arena"

Det første perspektiv "co-presence of independence and familiarity" illustrerer det forhold, at man ikke er fremmed over for den faglighed, som man studerer. Læringsteamets medlemmer har kundskab og holdninger knyttet til de hændelser, og de indsatser, som bliver observeret. Det vil derfor være en manipulation, hvis man foregøgler, at man "bare" observerer. Formålet er derfor at bringe disse aspekter i spil og gøre dem værdifulde for de individuelle og kollektive læreprocesser. Med andre ord give deltagerne kvalificeret fagligt med- og modspil, når man eksempelvis diskuterer håndteringen af en bestemt type hændelser, eller diskuterer en given situation, som indsatslederen har stået i.

Det andet aspekt er knyttet til forskerens rolle i forhold til at give "formative advice", forstået som at give den opnåede erkendelse tilbage til holdlederne og indsatslederne. Et centralt aspekt af dette arbejde er naturligvis at betone læringsteamets uafhængighed, når teamets medlemmer, qua deres rolle som forskere, understøtter visse diskurser, og fornægter andre. I den konkrete case er det særligt en udfordring på informations- og læringsdage, hvor formålet netop er at skabe et læringsudbytte, som alle kan få udbytte af. I en sådan proces er det nødvendigt løbende at balancere arbejdet med at fastholde det, der fungerer efter hensigten, og på den anden side bearbejde afvigelser, eller mindre gode indsatser, på en produktiv måde.

Det tredje perspektiv er, at deltagerne i et observationsstudie ikke blot skal forstås som reflekterende praktikere (Schön, 1983), der forholder sig til, hvad de gør i deres hverdag, og hvordan de gør det. De skal i højere grad forstås som værende refleksive praktikere, der væver deres arbejde sammen med deres identitet. Man skal derfor, som forskere i egen profession, og som den enkeltes kollega, være klar til at indgå i interaktion og dialog. Lewis and Russel betegner dette som, at forskeren skal være klar til at indgå i en "dialectic arena" (Lewis \& Russell, 2011, s. 401). Man bliver med andre ord trukket ind i diskussioner og konflikter, og det er ofte ikke muligt blot at blive i sin undersøgende position. Man vil ofte blive afkrævet et svar, og man bliver nødt til at positionere sig i disse diskussioner. Derved vil der også fra tid til anden kunne være situationer, hvor man som læringsteam har forskellige anskuelser, hvilket jo blot understreger, at sandheden om den gode praksis ikke kan reduceres til rigtig/eller forkert.

\section{Kropskameraets funktionalitet}

Anvendelsen af kamera under indsatser i Beredskab Øst er en frivillig ordning. Optagelserne tilhører den enkelte, og det er den enkelte holdleder eller indsatsleder, der sætter begrænsningen for, hvorvidt læringsteamet skal inkluderes. Formålet med anvendelse af kamera, under indsatser og øvelser, er alene at give mulighed for, at individet og organisationen kan reflektere og lære af optagelserne. Det kropskamera, der benyttes i Beredskab

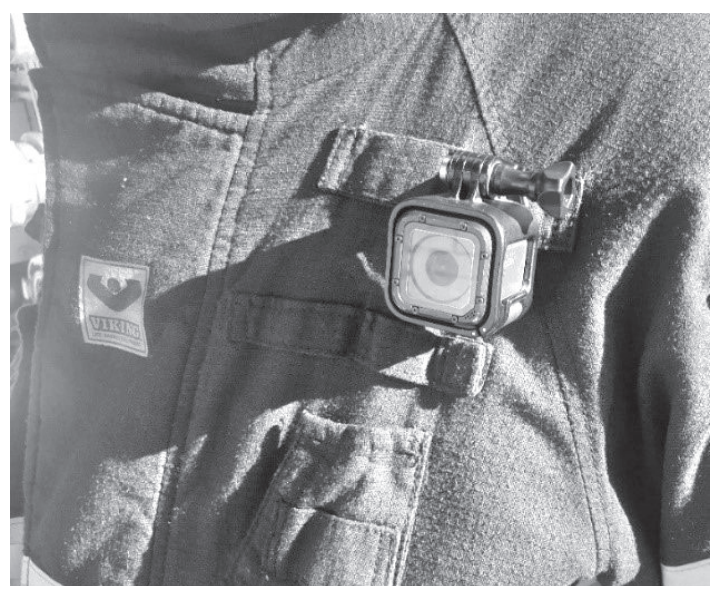

Billede 1. Placering af kropskamera på indsatsdragt, (C) Beredskab Øst 
Øst, er af typen "GoPro Hero4 session". Kameraet sidder i en clips, som man sætter i en strop på dragten. Kameraet sidder, så det er synligt, og derved får den bedste vinkel at optage fra. Derudover så er placeringen, som vist på billedet, med til at sikre, at kameraet ikke er i vejen for andet udstyr, såsom radioer etc. Når kameraet optager, er der en rød diode, der blinker kontinuerligt, så det er åbenlyst for alle, hvornår kameraet optager.

Kameraet gemmer optagelsen på et SDkort. Det er den enkelte holdleder eller indsatsleder, der håndterer datamaterialet, når man returnerer fra en indsats. Materialet bliver herefter snarest overført til en krypteret ekstern harddisk, der opbevares aflåst. Såfremt holdlederen eller indsatslederen mener, at optagelserne kan have generel interesse, så inddrages læringsteamet, der forestår den individuelle feedback, såvel som den videre bearbejdning frem mod anvendelse på fælles informations- og læringsdage.

\section{Undersøgelsesdesign - fra kameraoptagelse til etisk dilemma}

Beredskab Øst håndterer hvert år ca. 2700 udrykninger, hvilket betyder, at der hvert år bliver optaget mange timers indsatser. I analysen har vi udvalgt kritiske cases, der alle indeholder en vis grad af kompleksitet. Analysen tager afsæt i førsteindsatsen frem til overgangen hen mod den endelige indsats. Det er valgt for at fokusere på den mest hektiske fase af indsatserne, hvilket indeholder langt størstedelen af de forstyrrelser, der rammer den enkelte. Optagelserne af de enkelte cases er grundlæggende udleveret fra den indsatsleder eller holdleder, der har optaget indsatsen. Herefter foretager læringsteamet en transskription af dialogen. Den indledende analyse består af en registreringsdel, en indsatsbeskrivelse og endelig en læringsbeskrivelse samt en afdækning af de potentielle etiske dilemmaer. Registreringsdelen består grundlæggende i at fastlægge tid og sted, herunder hvilke enheder, der er disponeret. Herefter genafspilles optagelsen igen, og selve indsatsen bliver beskrevet. Indsatsbeskrivelsen har med andre ord til formål at fastlægge de centrale skift i den "historie", som udspiller sig. Det kan eksempelvis være at registrere, hvilke enheder der håndterer hvilke opgaver, hvad de taler om mv. 15 minutters optagelse giver ca. 30 ID.numre afhængig af indsatsens type og kompleksitet. Indsatsbeskrivelsen for Case B. ser eksempelvis sådan ud:

\begin{tabular}{cll} 
ID.nr. & Tid & Beskrivelse \\
\hline 1 & $00: 15$ & $\begin{array}{l}\text { HL1 modtager tur, HL1 siger: eksplosion på en byggeplads af en slags, } \\
\text { personer răber om hjælp. }\end{array}$ \\
\hline 2 & $01: 16$ & $\begin{array}{l}\text { CHF forklarer, hvor den konkrete vej går fra. Men er usikker på } \\
\text { hvor byggepladsen konkret ligger. }\end{array}$ \\
\hline 3 & $01: 30$ & Supplerende melding, regionen afsender 2 ambulancer og 1 akutlæge. \\
\hline 4 & $02: 00$ & Der kommer supplerende melding om, at der er sprængstof i udgravningen. \\
\hline 5 & $02: 43$ & ISL kalder op, og beder HL1 om at holde "behørig afstand". \\
\hline
\end{tabular}

Indsatsbeskrivelse "Case B. Arbejdsulykke". 
Hvert element i indsatsbeskrivelsen har et ID.nr., og dette ID.nr. bliver videreført i læringsbeskrivelsen. Læringsbeskrivelsen er her, hvor læringsteamet går ind, og afdækker det kollektive læringspotentiale. Der spørges med andre ord til, hvordan det, der sker i eksempelvis ID.26, har potentialet til at initiere reflekterende eller refleksive læreprocesser, såfremt læringspunktet blev foldet ud kollektivt.

Læringsbeskrivelsen ser eksempelvis sådan her ud:

\begin{tabular}{|c|c|c|}
\hline ID.nr. & Tid & Beskrivelse \\
\hline 1 & $00: 15$ & $\begin{array}{l}\text { HL1 læser højt formodentlig med henblik på at mentalforberede mandskabet } \\
\text { på den alvorlige karakter i meldingens ordlyd. Dette er i overensstemmelse } \\
\text { med almindelig praksis. }\end{array}$ \\
\hline 2 & 01:16 & $\begin{array}{l}\text { Chaufføren virker meget usikker på adressen og påvirket af den alvorlige } \\
\text { karakter i meldingens ordlyd - dette bør afklares af HL1 ved at slå adressen op } \\
\text { så denne stresspåvirkning fjernes fra brandmanden. Tvivlen italesættes flere } \\
\text { gange af chaufføren. }\end{array}$ \\
\hline 3 & 01:30 & - \\
\hline 4 & $02: 00$ & $\begin{array}{l}\text { Det virker ikke som om, at der er nogen, der opfatter, at der er tale om } \\
\text { sprængstof - dette underbygges af at HL1 senere i indsatsen italesætter, at der } \\
\text { ikke har været udslag på gasdetektor. }\end{array}$ \\
\hline 5 & $02: 43$ & $\begin{array}{l}\text { Holde behørig afstand kan fortolkes meget forskelligt. Normal sikkerhedsaf- } \\
\text { stand til eksplosiver er } 1000 \text { meter. Det må anses for at være urealistisk i denne } \\
\text { opgaveløsning, der involverer personredning. Hvis det er gas, er sikkerheds- } \\
\text { afstanden } 100 \text { meter. Så hvad HL1 har at rette sig efter er svært at sige. Dette } \\
\text { peger ikke alene på ISL men ligeledes på HL1 der bør rejse dette spørgsmål. }\end{array}$ \\
\hline
\end{tabular}

Afslutningsvis undersøges det, om udfoldelsen af det konkrete læringspunkt er forbundet med nogle etiske dilemmaer. Dilemmaer forstås i forlængelse heraf som spændingsfeltet i de konsekvensetiske perspektiver - altså forholdet mellem den kollektive læring versus de omkostninger, den konkrete deling har for individet.

\section{Undersøgelse af etiske dilemmaer knyttet til faktiske hæendelser}

I det følgende analyseres 3 cases, der anskueliggør de udfordringer, der opstår i forhold til at balancere læringsudbyttet fra de operativ indsatser, over for de etiske dilemmaer, der opstår.

\section{Analyse A. Case A. "Flere biler i brand under fritliggende garage"}

\section{Indsatsbeskrivelse}

Beredskabet modtager en melding om flere biler, der brænder i en række fritliggende garager. Der afsendes en indsatsleder samt en "station", bestående af sprøjte og tankvogn. Kameraoptagelsen er foretaget af holdlederen, der ankommer først til stedet. Allerede under 
fremkørslen kan mandskabet se ildskæret, og det bliver tydeligt, at der er tale om en større brandudbredelse. I forlængelse heraf vælger indsatslederen at kalde mandskab fra endnu en station. Under fremkørsel forsøger holdlederen at kalde sin tankvogn, dog uden held. Holdlederne taler med mandskabet omkring den konkrete håndtering af hændelsen, og det bliver aftalt, at man skal benytte trykluftskum og vand. Da man ankommer til stedet, opstår der lidt forvirring om arbejdsdelingen, da tankvognen ikke har fået besked om, hvad deres konkrete opgave er. De vælger derfor at hjælpe med at trække slangen frem. Holdlederen ønsker, at mandskabet fra vandtankvognen skal tage en hjælpeslange med trykluftskum fra sprøjten, med henblik på at lave endnu et angreb. Der bliver i den forbindelse italesat tvivl om, hvor tankvognen skal holde. Derudover italesætter mandskabet tvivl om, hvorvidt de skal prioritere vandforsyning, eller om tankvognen skal prioritere at slukke brand.

\section{Loeringsbeskrivelse}

Udgangspunktet for enhver operativ indsats er en situationsbedømmelse, men i den konkrete hændelse, bliver de væsentlige parametre i situationsbedømmelsen (situation, opgave og udførelse) aftalt under fremkørslen. Holdlederen kan dog ikke få kontakt med vandtankvognen, og de har derfor ikke fået besked om, hvad holdlederen ønsker at få foretaget. Ved ankomst til brandstedet går mandskabet fra sprøjten i gang, og mandskabet fra tankvognen hjælper med at trække slanger frem. Herefter vil holdlederen gerne have mandskabet fra tankvognen til at lave et selvstændigt angreb, men mandskabet kender ikke opgaven samt den ønskede udførelse. Holdlederen får i hændelsen låst sig fast under fremkørslen på én konkret håndtering, og det er sårbart, særligt hvis hændelsen er markant anderledes end forventet. I den konkrete hændelse opstår der tvivl hos brandmandskabet om deres konkrete opgaver, og udførelse er altså ikke blevet kommunikeret tilstrækkeligt præcist ud. Ved at planlægge indsatsen under fremkørslen udsætter holdlederen sig også for den risiko, at man bliver for ambitiøs i forhold til den konkrete operative indsats. At man som holdleder, eller indsatsleder, låser sig fast på ét plan, og generelt er for overambitiøs i sin indsættelsesmetodik, er en udfordring, som læringsteamet ofte støder på. Den konkrete hændelse bidrager ren læringsmæssigt med et klart eksempel på, hvordan man ikke bør gøre. Der er altså dels et konkret individuelt læringspunkt rettet mod holdlederen, men i lige så høj grad et læringspunkt rettet mod kollektivet.

\section{Etiske dilemmaer}

Selvom der i den konkrete hændelse var flere biler, der brændte, så er bilbrande hverdagshændelser, der bliver løst ud fra en fast modus operandi. Hændelsen som sådan påkaldte sig derfor ikke den store opmærksomhed. Det specielle var, at der i organisationen efterfulgt blev efterspurgt optagelser, hvor der blev anvendt trykluftskum. Hændelsen var derfor relevant, og holdlederen delte sin optagelse i en mail rettet mod læringsteamet, hvor der stod "I bruger det selvfølgelig bare som I kan og vil". Herefter gik de enkelte medlemmer af læringsteamet hver især i gang med at analysere videoen, og resultatet blev feedback fra samtlige af læringsteamets medlemmer. Feedbacken gik mere på situationsbedømmelse, herunder ressourceudnyttelse, end på anvendelsen af trykluftskum. Holdlederen har efterfølgende forklaret, at vedkommende var tilfreds med feedbacken, men at det var overvældende. Der skete i den konkrete situation det, at holdlederen troede, at fokus i evalueringen var på brugen af et konkret værktøj - trykluftsskum. Pludselig ændrer 
fokus sig til at handle om holdlederens holdlederpraksis. Selvom det konkrete eksempel var meget klart, og altså var oplagt som eksempel på de mulige misforståelser, der kan opstå af en uklar befaling, så var det grundlæggende et fokus, der var konstrueret fra læringsteamet - ikke fra holdlederen selv. I det konkrete tilfælde var der givet samtykke, men den konkrete samtykke var for udefineret. Holdlederen svarer på en henvendelse om et slukningsmiddel, og pludselig handler feedbacken om holdlederens operative praksis. I forhold til repressalier er der ikke tale om alvorlige afvigelser, det er blot et eksempel på en gængs udfordring. Den konkrete holdleder var dog på dette tidspunkt relativt ny, og derfor er det særligt udfordrende, hvis man vælger netop at bruge en sådan holdleder til at anskueliggøre en generel pointe, som andre, og mere rutinerede holdledere, også kunne have lavet. I det konkrete tilfælde blev optagelsen anvendt på interne informationsog læringsdage, men optagelsen blev klippet sammen på en sådan måde, at fokus var rettet mod kommunikationen mellem brandfolkene og holdlederne. Fokus blev derved rettet mod den mere generelle problematik, og ikke mod holdlederens mangelfulde befaling.

\section{Analyse B. "Arbejdsulykke"}

\section{Indsatsbeskrivelse}

Beredskabet bliver alarmeret til en arbejdsulykke på en byggeplads, hvor der har været en eksplosion i forbindelse med nogle udgravninger. Kameraoptagelsen er filmet af holdlederen fra den primære station, der møder på stedet samtidig som indsatslederen. Mandskabet bliver mødt af nogle borgere, der kommer slæbende med en alvorligt såret person. Indsatsleder og sprøjten holder afstand til hændelsen, og der er en hel del radiokommunikation, hvor især vagtcentralen er interesseret $i$, om der er oprettet opmarchområde, hvor tilstødende styrker skal placere sig. Indsatsleder tager ekstra radioer med, og begiver sig sammen med holdlederen frem til skadestedet. Her bliver indsatslederen stående gennem hændelsen, hvorimod holdlederen går ud, og tager fat i den assisterende station, der også er tilkaldt. Der opstår i forbindelse med hændelsen den udfordring, at man skal have spærret effektivt af, så civile biler mv. ikke kører ind i fareområdet. Ligeledes er det væsentligt, at politiet samt sundhedsberedskabet ikke kører ind i fareområdet, eftersom de ikke har mulighed for at iklæde sig det nødvendige beskyttelsesudstyr.

\section{Loeringsbeskrivelse}

Alvorlige eksplosionsulykker hører til en kategori af hændelser, som beredskabet sjældent håndterer. Alene af den grund er en sådan hændelse interessant for læringsteamet med henblik på kollektiv læring. I forhold til særligt indsatslederens virke, er der flere væsentlige forstyrrelser, som det er af generel interesse at reflektere over. En af disse forstyrrelser er fastlæggelsen af fareområdet, herunder indsatslederens tilgængelighed på skadestedet. Indsatslederen har ansvaret for den tekniske ledelse af indsatsen på selve skadestedet, herunder de overordnede forhold omkring personellets sikkerhed og arbejdsvilkår. I den indledende del af indsatsen er det derfor nødvendigt, at indsatslederen befinder sig uden for et eventuelt fareområde, og er synlig og let tilgængelig for indsatslederne fra de øvrige sektorer, hvilket ikke sker i den konkrete indsats. Indsatslederen skal medvirke til at opnå og fastlægge en fælles situationsforståelse, herunder udpege et eventuelt fareområde og fastlægge, hvad faren består i. Indsatslederen vælger i den konkrete hændelse, at blive inde i selve fareområdet, hvorfra indsatslederen koordinerer opgaver, som reelt set kunne håndteres af 
holdlederen. På den baggrund opstår der et ledelsesvakuum, hvilket bevirker, at holdlederne vælger at bryde kommandovejen, og begynder at koordinere arbejdsopgaverne imellem sig. Hændelsen er speciel, og der er flere alvorligt tilskadekomne, og det er derfor forståeligt, at alle fra indsatsmandskabet bliver påvirket, og i et vist omfang bliver ramt af tunnelsyn. Eksempelvis tager indsatsleder-brand yderligere 2 radioer med fra sin indsatslederbil, så han totalt set medbringer 4 radioer. Dette kan tolkes som et udtryk for, at indsatslederen føler behov for at koordinere hændelsen med mange forskellige aktører, men det ender reelt set med at virke modsat, og indsatslederen får fastholdt sin position helt inde ved fareområdet.

\section{Etiske dilemmaer}

Hændelsen viser et generelt læringspunkt omkring fastlæggelse af fareområdet, herunder de udfordringer det afstedkommer, hvis man som indsatsleder bliver fastlåst, og ikke lykkes med at trække sig på afstand af den konkrete problemløsning. Det at fastlægge et fareområde er et af grundelementerne i den formelle indsatslederuddannelse. I den konkrete case, opstår der den udfordring, at en ellers rutineret indsatsleder laver nogle grundlæggende uhensigtsmæssigheder. Der opstår i den forbindelse en udfordring i forhold til at sikre, at indsatslederen "ikke klædes af", eller oplever andre former for kulturelt betingede repressalier. I praksis kan dette være vanskeligt, særligt hvis den konkrete afvigelse er særlig alvorlig. I de få situationer, hvor dette konkret har været tilfældet, bliver der fulgt op med personlig feedback af repræsentanter fra læringsteamet. Fokus er her ikke på at udskælde individet, men netop gøre det muligt for individet at reflektere over det hændte. I den forbindelse bliver det også muligt at opsummere gældende procedurer samt afdække et potentielt træningsmæssigt behov. I disse situationer bliver den individuelle læreproces altså skærmet fuldstændig fra de kollektive læreprocesser, såfremt læringsteamet eller individet vurderer, at en kollektiv eksponering vil forplumre individets mulighed for at lære af hændelsen. Resten af organisationen ved dog godt, at den konkrete hændelse har været der, så det er ikke hensigten at mørklægge sagen. I stedet var det i den konkrete case nødvendigt at inddrage individet aktivt, så man kan få dele af indsatsen bearbejdet kollektivt. De aspekter, der i høj grad er forbundet med skyld og skam, bliver så bearbejdet i et mere intimt forum mellem læringsteamets medlemmer og det enkelte individ.

\section{Analyse C. "Bygningsbrand"}

\section{Indsatsbeskrivelse}

Beredskabet modtager en melding om bygningsbrand på en institution, hvor anmelderen siger, der er begyndende brandspredning til en rideskole. Der afsendes indsatsleder, indsatsleder-bagvagt samt 3 udrykningsenheder, der hver møder med en holdleder. Holdlederen, der optager hændelsen, får besked om at køre direkte til skadestedet. Det fremgår af optagelsen, at holdlederen ikke kender vejen, og der er en del forskellige bud på, hvor de skal hen. Holdlederen beslutter afslutningsvis at køre efter GPS'en, der fører dem til brandstedet. Ved ankomst kan de se en bygning, hvor det brænder i gavlen med begyndende brandspredning til resten af konstruktionen. Indsatslederen beder holdlederne om at køre til siden, hvorefter holdlederen bliver indsat med sit mandskab til at slukke branden på bygningens første sal. Det bliver fastlagt af indsatsleder, at dette skal gøres ved hjælp af en skæreslukker, der er i 
stand til at skære gennem konstruktionen, og herefter få vand ind, og derved slukke branden.

\section{Loeringsbeskrivelse}

Selve hændelsen med en bygningsbrand, der potentiel kan sprede sig, er i sagens natur en alvorlig hændelse, men er som sådan velkendt for beredskabet. Selvom stemningen i sprøjten under fremkørslen er rolig, så bliver tiden under fremkørslen ikke anvendt optimalt. Holdlederen kunne have valgt at slå bygningen op i de forskellige systemer, som holdlederen råder over under fremkørslen. Holdlederen kunne have valgt at kigge nærmere på den lokation, som sprøjtens GPS kom op med indledningsvist. Alternativt kunne holdlederen have valgt at benytte sin Ipad til at slå bygningen op i Bygnings- og Boligregistret eller for den sags skyld Google Maps. Derudover er der en række informationer omkring eksempelvis brandhaner, tekniske kort, satellitkort mv., som holdlederen kunne finde i det GIS-system (Geografisk Informationssystem,), som er tilgængeligt på holdlederens Ipad. Ingen af disse ting bliver gjort, og holdlederen møder derfor uforberedt op på skadestedet, hvilket afviger fra de vanlige operative procedurer.

Selvom både indsatsleder og holdlederne er rutinerede folk, så går der forholdsvist længe, inden der bliver indsat med et relevant slukningsmiddel på ildebranden. Dette er uheldigt, da brandforløbet derved potentielt får lov til at udvikle sig. Holdlederen, som optager, bliver indledningsvis ikke indsat, hvilket skyldes, at indsatslederen gerne vil have en anden udrykningsenhed fra primærstationen indsat først. Da holdlederen bliver indsat med skæreslukkeren, så vælger holdlederen og indsatslederen ikke at benytte deres termiske kamera, der ellers er oplagt $\mathrm{i}$ en sådan situation. Det termiske kamera gør det muligt at måle, hvor konstruktionen er mest opvarmet, og derved kan man lokalisere branden. I stedet for at bruge det termiske kamera, så vælger holdlederen i stedet at tage billeder med sin telefon, der videresendes som dokumentation. Dokumentation kan naturligvis være centralt, men i den indledende fase af ildebranden er fokus på branden i sagens natur vigtigere.

\section{Etiske dilemmaer}

Optagelserne fra bygningsbranden illustrerer nogle udfordringer knyttet til at benytte tiden og ressourcerne fornuftigt under fremkørslen til skadestedet. Det er væsentlige læringspunkter, som er værdifulde at reflektere over kollektivt. Derudover viser hændelsen vigtigheden af, at holdlederen har fokus rettet mod sit hold, og mod at understøtte brandholdets opgave. Der er derved også centrale refleksive pointer knyttet til både holdlederen samt indsatslederens ledelsesvirke. Udfordringen i forhold til at anvende den konkrete optagelse rent læringsmæssigt er, at man potentielt set udstiller nogle enkeltpersoner, der tager nogle uheldige valg. Holdlederen, der optager, er en rutineret holdleder, og hvis man er i tvivl om, hvor man skal hen, så er det ikke nok at gætte og være i tvivl, så må man gøre noget aktivt for ikke at være i tvivl. Som skitseret er der en række muligheder for at indhente viden, men der bliver ikke foretaget noget. Den samme pointe gør sig gældende i forhold til indsættelsen af holdlederens mandskab. Det er en markant afvigelse fra standarden, at man begynder at dokumentere hændelsen, inden at man har sikret sig grundlæggende information om den opgave, man har fået.

De afvigelser, der opstår i den konkrete hændelse, er rent etisk problematisk på forskellige måder. Først og fremmest er der tale om banale fejl, som en rutineret holdleder laver. En eksponering af disse afvigelse vil potentielt føre nogle kulturelt betingede repressalier med sig. Det kunne være sladder 
eller tab af status. En eksponering af den praksis, som er skitseret i "Case C." kan være vanskelig at håndtere, hvis man har en position i organisationen, hvor man er en af de rutinerede holdledere eller indsatsledere. En eksponering i en sådan situation vil i sagens natur afstedkomme en reaktion, som ikke fordrer læring, men som i højere grad vil afstedkomme frustration og sårbarhed, og derved grundlæggende vil virke uproduktivt for de individuelle såvel som kollektive læreprocesser. Derudover opstår der en anden etisk udfordring i forhold til relationen til læringsteamet. Det er læringsteamet, der udarbejder, underviser samt vedligeholder de operative forhold, som man arbejder med i beredskabet. De konkrete afvigelser i casen vedrører altså direkte læringsteamet. Der opstår derved den udfordring, at det er læringsteamet, der skal skabe en tryg ramme for læring for individet. Samtidig er læringsteamet en part i sagen, eftersom det er læringsteamets procedurer, som ikke bliver fulgt. Det er derfor nødvendigt, at læringsteamet kigger ud over egne behov, og egne retningslinjer, og i stedet ser på individets behov. Den individuelle læreproces skal dog heller ikke legitimere, at man ikke følger de vedtagne procedurer mv., og det er denne balance, som læringsteamets medlemmer bliver nødt til at være bevidste om.

\section{Kunsten at balancere hensynet til individet}

Analysen viser, at det, der potentielt gør mest ondt på enkeltpersoner, samtidig er de læringspunkter, som indeholder det største kollektive læringspotentiale. En god læringsbegivenhed er så tilstrækkelig potent, at den afstedkommer oplevelser af at blive ramt. Det er denne oplevelse, der bidrager med energi til de reflekterende og refleksive læreprocesser for individet såvel som for kollektivet. Denne energi er afgørende for, at den enkelte oplever lysten og viljen til at udvikle sig som professionsudøver. Ofte bliver det taget for givet, at alle har viljen og lysten til at lære, men erfaringerne fra arbejdet i læringsteamet viser, at det er langt vanskeligere i praksis. For at en læringsbegivenhed virkelig skal flytte individet, så skal der være noget på spil. Et læringspunkt skal ideelt set være så tilpas tydeligt og energifyldt, at både individet samt kollegaerne kan få en oplevelse af at blive ramt. I forhold til de kollegaer, der ikke er en del af den konkrete hændelse, så er det vanskeligt at skabe afsæt for refleksive læreprocesser. Målet er i højere grad at initiere en reflekterende læreproces, hvor den enkelte bliver udfordret på, hvad den enkelte teknisk og taktisk ville gøre, hvis de stod i en lignende situation. Det vanskelige i dette arbejde er, at læring ikke gør lige ondt på alle. Graden af, hvor ondt læringen gør, er betinget af alvoren i den konkrete afvigelse, men er også betinget af den rolle og funktion, som den enkelte har i organisationen. De refleksive læreprocesser knyttet til individet er dem, der er mest sårbare, eftersom de ofte er forbundet med skyld og skam relateret til ikke at have præsteret som håbet, eller forventet. Disse individuelle læreprocesser bør derfor behandles omhyggeligt og med respekt, da de konsekvensetisk påfører individet skyld og skam, og helt grundlæggende kan vanskeliggøre vilkårene for de individuelle læreprocesser. Denne type af kontroversielle refleksive læreprocesser bør derfor i højere grad udfoldes gennem dialog og feedback mellem den enkelte og læringsteamet. Hvis det ikke lykkes at skabe nogle trygge rammer for de individuelle læreprocesser, så rammer det for det første individet, men stopper for det andet "fødekæden" af læringsmateriale til den kollektive læring.

Foruden rammer, der sikrer tryghed til de sårbare individuelle læreprocesser, så viser analysen nødvendigheden af, at det skabes reelt samtykke, herunder foretages en for- 
ventningsafstemning mellem den personer, der stiller optagelsen til rådighed, og læringsteamet. Ellers ender man i den situation, som der opstår i "Case A.", hvor holdlederen giver et meget frit og bredt mandat til brugen af optagelsen. Læringsteamet går herefter $\mathrm{i}$ kødet på optagelsen, hvilket resulterer i en række forskellige analyser, der alle har det til fælles, at fokus er rettet mod læringspunkter, der er knyttet til holdlederens operative praksis. Det er derfor nødvendigt at læringsteamet vender tilbage til disse konkrete personer, så der kan indhentes den fornødne samtykke. Processen med at indhente samtykke fra de involverede kan være en tung proces, men analysen har vist, at det er nødvendigt.

Selvom der ikke er tale om ansættelsesmæssige repressalier, så viser analysen, at det er vanskeligt at balancere de situationer, hvor der er kollegaer, der gør nogle ting, der strider med den gængse opfattelse af, hvad der er den korrekte modus operandi. Disse afvigelser kan naturligvis være et resultat af meget specielle hændelser, som i "Case B", men det kan også være afvigelser knyttet til mere hverdagslignende hændelser, som det er tilfældet i "Case C". Tolerancen, for hvad der gængs opfattes som acceptabelt, er naturligvis ikke ens på tværs af de enkelte hændelser. Særligt spørgsmålet omkring fareområdet i "Case B" samt den sene håndtering af brandforløbet i "Case C" er problematisk, eftersom der er tale om grundlæggende afvigelser fra kendte operative procedurer. Selvom det er velkendte afvigelser, der repræsenterer yderst relevante læringspunkter, så vil en eksponering udstille det enkelte individ uproduktivt, hvis det blev gjort til genstand for diskussioner, på læringsdage. I sådanne situationer er det derfor nødvendigt at trække de individuelle aspekter ud af den kollektive bearbejdning, og tage en mere individuel feedbacksession med den enkelte. Såfremt at den enkelte ikke ønsker at deltage i en sådan session med læringsteamet, så må man som læringsteam se bort fra at anvende en sådan optagelse. Dette er nødvendigt dels for at sikre individet mod indirekte repressalier, dels for at sikre, at man rent konsekvensetisk får fastholdt den generelle vilje og lyst i organisationen til at stille sig frem til glæde for de kollektive læreprocesser. Det kan dog grundlæggende være svært som læringsteam at "sidde på hænderne" i disse situationer, da det jo netop er her, der virkelig er noget, som kan danne baggrund for en ny og forbedret operativ praksis.

Arbejdet med denne artikel har været med til at udfordre læringsteamets praksis i forhold til de etiske udfordringer, der opstår mellem at balancere hensynet til den enkelte versus hensynet til de kollektive læreprocesser. Et konkret udbytte af denne erkendelse har været, at læringsteamet har valgt at ændre formen for bearbejdningen af de kollektive læreprocesser på de enkelte læringsdage. Overordnet set, så viser artiklens analyse, at der er behov for en tydeligere struktur i mødet mellem de individuelle- og kollektive læreprocesser. Det er helt grundlæggende uholdbart, at de oprindelige motiver for at benytte individets erfaringer bliver ændret, eftersom kollektivet pludselig ser noget andet, der måske bliver opfattet som mere interessant. Det vil eksponere individet, og pludselig vil individet få følelsen af at blive "set forkert". Formen på de fælles informations- og læringsdage er derfor blevet ændret, så der i forhold til gennemgangen af videooptagelserne arbejdes ud fra et mere stringent fokus end tidligere. Gennemgangen består nu af en redegørende faktuel del, en analyserende del samt en vurderende del. I den redegørende del bliver de grundlæggende faktuelle forhold klarlagt, herunder optagelsens tid og sted samt den situation, som møder holdledere og indsatsleder, ved ankomst. Herefter følger en analyserende del, hvor det enkelte individ, i samarbejde med læringsteamet, forud for den kollektive gennemgang har udvalgt specifik- 
ke forstyrrelser. Denne udvælgelse sikrer en mere struktureret undersøgelse med henblik på at anskueliggøre generelle læringspunkter. Afslutningsvis følger en vurderende del. Afsættet i den vurderende del er at diskutere de handlinger, der skal fastholdes i den konkrete hændelse. Herefter følger en diskussion af, hvad der kan blive bedre, og afslutningsvis afrundes med konkret at diskutere, hvordan man som kollektiv konkret kan arbejde i den ønskede retning. Artiklen har været med til at understrege, at rammerne for at anvende kropskameraet, som læringsunderstøttende teknologi, skal være mere entydige. Det har konkret betydet, at følgende pointer er blevet skrevet ind i den skabelon, som anvendes som afsæt for de kollektive læreprocesser på de månedlige informations- og læringsdage:

- Læring må godt gøre ondt, men det skal gøre "tilpas" ondt. Det forudsætter, at individet skal lære mindst lige så meget, som resten af gruppen.

\section{ReferenCer}

Bjørgo, T. \& Myhrer, T. (2015). Forskningsetisk veileder for Politihøgskolen. Politihøgskolen.

Bjørkelo, B. (2015). Det europeiske etiske regelverket for politiet. Politihøgskolen.

Bøhm, M. (2017). Oplevelser fra at blive ramt $i$ hverdagens operative indsatser - Brugen af hjelmkameraet som opmoerksomhedsunderstøttende teknologi. Ph.d.-afhandling, Roskilde Universitet.

Cunliffe, A. (2002). Reflexive Dialogical Practice in Management Learning. Management Learning, 33(1), 35-61.

Cunliffe, A. (2004). On Becoming a Critically Reflexive Practitioner. Journal of Management Education, 28(4), 407-426.

Diderichsen, A. (2011). Etik for politifolk: Samfundslitteratur

Due, J. \& Steen Madsen, J. (1999). Septemberforliget og den danske model. Baggrund, indhold og udvikling 1899-1999. København: Dansk
- Der findes ikke én sandhed, der findes mange. Undgå at spekulere i andres motiver.

- Udvis ydmyghed over for, at alle er klogere, "når røgen har lagt sig".

- Omtal funktion frem for person. Det er eksempelvis holdleder M1, der gør noget, ikke Jens.

- Der findes grundlæggende ikke fejlfri indsatser! Det afhænger kun af dybden af analysen.

Konkluderende må læring godt gøre ondt, men det skal gøre tilpas ondt, og det forudsætter, at læreprocesserne tager hensyn til det enkelte individs funktion og rolle i organisationen. Det er derfor nødvendigt at anlægge et forsigtighedsprincip - er man i tvivl om, hvorvidt den kollektive bearbejdning går ud over individets læreprocesser, så må tvivlen altid komme individet til gode. Derved sikrer man, at individets psykiske arbejdsmiljø bliver målet, og ikke blot midlet til kollektiv læring.

Arbejdsgiverforening, Landsorganisationen i Danmark.

Elkjaer, B. (2004). Organizational Learning: The "Third Way". Management Learning, 35(4), 419-434.

Lewis, S. \& Russel, A. (2011). Being embedded: A way forwards for ethnographic research. Ethnography,12, 398-413.

Mezirow, J. (1990). Fostering Critical Reflection in Adulthood - A Guide to Transformative and Emancipatory Learning. San Francisco: Joessey-Bass Publishers.

Preissle J. \& Grant, L. (2004). Fieldwork Traditions: Ethnography and Participant Observation. In K. deMarrais \& S. Lapan., Foundations for Research - Methods of Inquiry in Education and the Social Sciences (s. 161-181). London: Lawrence Erlbaum Associates, Publishers. 
Schön, D. A. (1983). The reflective practitioner: how professionals think in action. New York: Basic Books.

Sommer, M. (2015). Learning in emergency response work. PhD Dissertation, Faculty of Science and Technology, Department of Industrial Economics, Risk Management and Planning, University of Stavanger.

Sommer, M. \& Njå, O. (2011). Learning amongst

Norwegian fire-fighters. Journal of Workplace Learning, 23(7), 435 - 455.

Spradley, J. (1980). Participant Observation. New

York: Holt, Rinehart and Winston,.

\section{OrdForkLARING}

I artiklen benyttes følgende fagtermer (Beredskabsstyrelsen, 2018):

\section{Fareområde}

Det område, eller den lokalitet inden for indre afspærring, hvor der er en konkret fare for personer. Fareområdet, som typisk forekommer ved hændelser med farlig kemi, biologi, eksplosionsfare, kraftig røgudvikling eller fare for sammenstyrtning, fastlægges af indsatslederen fra brandvæsenet. Ved nogen hændelser fastlægges fareområdet $\mathrm{i}$ samarbejde med et relevant ekspertberedskaber. Kun personel med særligt beskyttelsesudstyr har som udgangspunkt adgang til fareområdet.

\section{Førsteindsats}

Den foreløbige indsats, der tilsigter at yde den indledende hjælp til tilskadekomne og umiddelbart truede personer samt at hindre udbredelse af en skade. Når førsteindsatsen er iværksat, har indsatsledelsen mulighed for at gennemføre en nøjere rekognoscering af hele skadestedet, med henblik på iværksættelsen af den endelige indsats.

\section{Holdleder}

En holdleder i redningsberedskabet er en person ansat og uddannet til at varetage den direkte ledelse af brandmandskabet i at slukke brande,
Statens Samfundsvidenskabelige Forskningsråd (2002). Vejledende Retningslinjer for Forskningsetik i Samfundsvidenskaberne, Danish Social Science Research Council, https://ufm. $\mathrm{dk} /$ publikationer/2002/vejledende-retningslinier-for-forskningsetik-i-samfundsvidenskaberne (Tilgået 14. marts 2019).

Watson, T. J. (2011). Ethnography, Reality, and Truth: The Vital Need for Studies of 'How Things Work'. In Organizations and Management. Journal of Management Studies, 48(1), 202-216.

foretage redningsopgaver og håndtere akutte uheld med farlige stoffer. Holdlederen har i udgangspunktet et brandmandskab på fem personer til sin rådighed. Holdlederen er typisk underlagt en indsatsleder.

\section{Indsatsledelsen}

Indsatsledelsen er det samarbejdsforum, hvor relevante ledere indgår, og som under koordination af politiet har det overordnede ledelsesmæssige ansvar for gennemførelsen af en beredskabsmæssig indsats. Grundstammen i indsatsledelsen udgøres af indsatslederne fra politiet, redningsberedskabet og sundhedsberedskabet.

\section{Indsatsleder Brand}

Den person fra det kommunale redningsberedskab (brandvæsenet), der varetager den tekniske og taktiske ledelse af indsatsen på et skadested, og som har det overordnede ansvar for alle indsatte enheders sikkerhed inden for indre afspærring. Indsatslederen udøver sin kommando gennem holdlederne.

\section{Teknisk leder}

Redningsberedskabets leder af den tekniske og taktiske indsats på et skadested. Dette kan enten være en holdleder eller en indsatsleder. 
Mikkel Bøhm, lektor, ph.d.

Københavns Professionshøjskole og Beredskabsinspektør ved Beredskab Øst, e-mail: boe@beros.dk

Jan Bendtzen, beredskabsinspektør, Beredskab Øst

e-mail: jabe@beros.dk

Michael Jensen, viceberedskabsinspektør, Beredskab Øst e-mail: mje@beros.dk

Martin Brix Larsen, beredskabsinspektør, Beredskab Øst e-mail: mal@beros.dk. 